\title{
Evidence on equity, governance and financing after health care reform in Mexico: lessons for Latin American countries'
}

\section{Evidencias sobre gobernanza, equidad y financiamiento en salud en méxico: lecciones para paises latinoamericanos}

\author{
Armando Arredondo \\ National Institute of Public Health. Center for Health System Re- \\ search. Department of Health System Organization. Cuernavaca, \\ México. \\ E-mail: armando.arredondoळinsp.mx \\ Emanuel Orozco \\ National Institute of Public Health. Center for Health System Re- \\ search. Department of Academic Support. Cuernavaca, México. \\ E-mail: emanuel.orozcoळinsp.mx \\ Raúl Aviles \\ National Institute of Public Health. Center for Health System Re- \\ search. Department of Health System Organization. Cuernavaca, \\ México. \\ E-mail: raul.avilesळinsp.mx
}

\section{Correspondência}

Armando Arredondo

Av. Universidad, 655. Cuernavaca, Morelos, México. CP 62508.

\section{Abstract}

This article includes evidence on equity, governance and health financing outcomes of the Mexican health system. An evaluative research with a cross-sectional design was oriented towards the qualitative and quantitative analysis of financing, governance and equity indicators. Taking into account feasibility, as well as political and technical criteria, seven Mexican states were selected as study populations and an evaluative research was conducted during 2002-2010. The data collection techniques were based on in-depth interviews with key personnel (providers, users and community leaders), consensus technique and document analysis. The qualitative analysis was done with ATLAS TI and POLICY MAKER softwares. The Mexican health system reform has modified dependence at the central level; there is a new equity equation for resources allocation, community leaders and users of services reported the need to improve an effective accountability system at both municipal and state levels. Strategies for equity, governance and financing do not have adequate mechanisms to promote participation from all social actors. Improving this situation is a very important goal in the Mexican health democratization process, in the context of health care reform. Inequality on resources allocation in some regions and catastrophic expenditure for users is unequal in all states, producing more negative effects on states with high social marginalization. Special emphasis is placed on the analysis of the main strengths and weaknesses, as relevant evidences for other Latin American countries which

1 This Project was funded by International Development Research Centre-CANADA and National Council for Science and Technology-Mexico. 
are designing, implementing and evaluating reform strategies in order to achieve equity, good governance and a greater financial protection in health. Keywords: Governance; Health Financing; Equity; Lessons.

\section{Resúmen}

Este articulo incluye evidencias sobre equidad, gobernanza y financiamiento como resultado de la reforma de la salud en México. Partió de una investigación evaluativa de diseño transversal con análisis cualitativo y cuantitativo en servicios de salud para población no asegurada desarrollada durante 2002-20010 Bajo criterios de factibilidad técnica, política y financiera, siete estados mexicanos fueron seleccionados. Los datos se recopilaron a través entrevistas a profundidad con actores clave (proveedores, usuarios, líderes comunitarios, legisladores y directivos), técnica de consenso y revisión documental y estadísticas oficiales. El procesamiento y análisis de la información se realizó con los paquetes ATLAS-TI Y POLICY MAKER. La reforma en salud ha podido modificar la dependencia del nivel central; existe nueva formula de equidad; los lideres comunitarios y usuarios plantean la necesidad de implementar sistemas de rendición de cuentas en salud a nivel municipal y estatal; las estrategias de reforma no cuentan con mecanismos adecuados para una participación de todos los actores del sistema de salud, aún cuando la democratización en salud se constituyó como eje conductor de la reforma; los niveles de inequidad en la asignación de recursos y los gastos catastróficos en salud afectan de manera desigual, teniendo impacto negativo en los estados con marginación social. Enfasis especial se hace en una lista de fortalezas y debilidades que a manera de lecciones aprendidas se sugieren para lograr una mayor equidad, mejores niveles de gobernanza y mayor protección financiera en los proyectos de reforma en salud a nivel mundial y particularmente en América Latina.

Palabras clave: Gobernanza; Financiamiento en salud; Equidad; Lecciones.

\section{Introduction}

Changes in health policies, together with Mexico's new economic policy, have led to health sector adjustments that are included in the Health Sector's Reform (Frenk et al., 1994). The reform project like in others countries, seeks health care alternatives for the whole population that take into account income levels and health needs (EOHS, 2010; Exelle; Herdt, 2009; OCDE, 2011). There is a special interest in ensuring that those who need the service not be marginalized from the system and receive at least basic health coverage under the principles of financial protection, equitable access and good quality care (Alonso, 2012; México, 2009; Moser; Leon; Gwatkin, 2005).

During the first phase of health system reform, the SSA (Ministry of Health) began the consolidation of a national health system (México, 2013b; México, 2013a); the decentralization strategy was implemented in 12 of the 31 states in the country (México, 2010b; Franco; Gil; Álvarez, 2005). The legal and normative framework for decentralization included important guidelines for financing, equity and governance at the national, state and municipal levels. These guidelines were oriented more directly towards producing changes in financial resource allocation mechanisms, but did not involve in-depth, substantial changes in allocation mechanisms and financing alternatives for services at a local level (Horvath, 2002; Arredondo, 2011). During the second phase of health reform, continuing with strategy of decentralization, the proposal was to create a new public insurance for all uninsured citizens (Arredondo; Orozco, 2008; 2009; IMSS, 2011).

The major aim of Health reform has been to include the different social actors to make health democratization concrete, as well as the negotiation of resources, together with other sectors competing for social expenditure (Braveman; Gruskin, 2003; Cassels, 1995). This negotiation must be based on a better understanding of which financial resources are required by the sector at the three decisionmaking levels (national, state and municipal), what its priorities are and, what are the available mechanisms for the obtainment and allocation of financial resources. 
Definition of new strategies for financing policies for health services is a key issue in the Mexican health care reform. Equity, governance, and financing policies were set forth, directed to explore financing mechanisms and social actors to generate new financing alternatives with local resources to provide health services (México, 2012a; Arredondo et al., 2011). Health reform included initiatives to create new social participation mechanisms as well as political and financial management strategies that would allow for greater autonomy at the state and municipal levels for the creation of financing schemes for health services (Ranson, 2004; WHO, 2005).

In this context, the main objective of this paper is to identify different social actors and economic indicators that would allow us to determine the effects of changes in health financing, equity and governance in response to the following questions:

What have been the main strengths and weaknesses after health care reform in terms of governance, health financing and equity in México? Which are the evidences and lessons for other Latin American or middle-income countries which are designing, implementing and evaluating strategies for health care reform?

\section{Methods}

Results of this paper come from a cross-sectional study aimed towards the analysis of financing, governance and equity indicators for Mexican uninsured population. We conducted semi structured interviews and secondary data in seven Mexican states located in the southern, central and northern regions of Mexico. These states were selected according to the following criteria: 1) different socio-economic development, according to the
Marginalization Index (developed at the municipal level by the Population Board using indicators such as access to potable water, electrification, type of household, crowding living conditions, illiteracy, belonging to the formal economy, mean annual income, and a financial co-responsibility index determined by the state contribution vs. the federal contribution); 2) implemented strategies of health care reform, with changes in health service financing policies, resource allocation and social participation; 3) the existence of a data base with economic information (México, 2010a; México, 2012c); and 4) technical capacity in health financing policies and decentralization, as well as in the management of some financing indicators to support data collection and collaborate with the research team.

For the purpose of analysis, a regionalization was done, taking into account the following criteria: per capita income, Marginalization Index (México, 2012b), and epidemiological profile (epidemiological lag based on mortality rates at the state level). Some of the characteristics of the selected states are described in Table 1. States of region A report greater marginalization, lower public insurance indexes, as well as greater epidemiological lag. This situation contrasts with regions $\mathrm{B}$ and $\mathrm{C}$, which showed lower marginalization indexes, higher levels of public insurance and a smaller epidemiological lag). A noticeable difference between regions is the highest concentration of indigenous population in region $\mathrm{A}$, whose states concentrate close to $50 \%$ of this population at the national level.

Interviewing instruments were designed for four types of informants: decision-makers, health services providers, health services users and community/NGO leaders. These instruments had open questions for each of the project's conceptual dimen-

Table I - Characteristics of selected regions, 2012

\begin{tabular}{|c|c|c|c|c|c|c|c|}
\hline Region & Population & $\begin{array}{l}\text { Marginalization } \\
\text { index }\left(^{*}\right)\end{array}$ & $\begin{array}{l}\text { Public } \\
\text { insurance } \\
\text { index(*) }\end{array}$ & $\begin{array}{l}\text { Epidemiological } \\
\text { lag }\left(^{*}\right)\end{array}$ & $\begin{array}{l}\text { Indigenous } \\
\text { population } \\
\left(^{*}\right)\end{array}$ & $\begin{array}{l}\text { Political } \\
\text { party in } \\
\text { power }\end{array}$ & $\begin{array}{l}\text { Geographic } \\
\text { position }\end{array}$ \\
\hline A & 710982 & High & Low & High & High & Left & North \\
\hline B & 741037 & Medium & Medium & Medium & Medium & Center & Northern \\
\hline C & 7838010 & Low & High & Low & Low & Right & Central \\
\hline
\end{tabular}

Sources: Consejo Nacional de Población-INEGI-2000-2014. SSA, Anuarios Estadísticos sobre daños a la salud, 1998-2006. Secretaría de Salud. Salud: México 2001-2010. Información para la Rendición de Cuentas, México, 2010. 
sions. With respect to financing, decision-makers and providers were asked about financing sources and funds linked to reform policies. Regarding users and community leaders, their support for fundraising efforts of the state health system was explored. In matters of equity, informants who were linked to the health system were asked about the application of distribution criteria for resource allocation; with users and community leaders, out-of-pocket expenditures and financial protection experiences were explored. Finally, health governance was inquired with all groups of informants by asking them about processes, roles and participation mechanisms for healthcare, as well as local accountability practices.

A total of 240 semi structured interviews were applied in the seven selected states, with the support of three researchers experienced in data collection. Interviewed informants were: 60 decision-makers, including medical and administrative personnel; 60 service providers at health centers; 60 representatives of civil organizations, including municipal representatives and, finally, 6o members of health committees and users of services at first level of care units. The information was obtained through indepth semi-structured interviews, using a thematic guide with questions and requesting authorization to carry out the interview and record it.

The interviews were transcribed and analyzed using the ATLAS-TI software. During this procedure, the information was analyzed by using 12 thematic codes defined in function of the research objectives and the topics explored during the interviews. Once the interviews were codified, tables of contents were put together and a measurement scale was developed, based on the total number of references to a topic, by variable and type of informant. These tables were a fundamental element for defining the analysis of strengths and weaknesses of health reform. Subsequently, POLICY MAKER software was used to determine the actors' roles and their links to the execution of strategies for health policies. Finally, to validate field data and results, the Delphi technique was applied and three workshops were held with selected key personnel in each state for the presentation of results and the revision of documents related to changes in equity, financing, and governance policies after health care reform.

\section{Results}

\section{Results on health governance}

The highest levels on strengths in the area of governance were observed in all states. These strengths are linked to the identification of legal frameworks and regulations, the orientation of strategies for accountability and local spaces for decision-making. Other characteristics in the states refer to the development of governmental abilities and the strengthening of fundraising capacity. Strengths reported by the states also refer to the existence of community initiatives to improve well-being, the acknowledgment of spaces for community participation linked to governmental programs such as "Oportunidades" and to mechanisms for citizen inclusion that are exclusive to the health sector, like in the case of the Health Committees.

It is important to specifically highlight the aspect pertaining to community support to improve the health units. To a lesser degree, but also considered as strengths, are intergovernmental coordination and the existence of mediation mechanisms to support vulnerable groups. The strengthening reported by the three states also refers to the empowerment of users with the inclusion of new initiatives like the Popular Health Insurance, since they contribute direct and specific benefits, and an interest in a greater participation of citizens in healthcare (see Table 2).

Governance weaknesses refer to the lack of coordination between government levels and to political dimensions such as influence peddling or cronyism. Centralism and the limited channels to promote participation in financing and in the management of health systems are also weaknesses expressed by the analyzed states.

The weakness in governance that is mostly reported in regions $A$ and $B$ is that of political corporatism or a patronage system (favoritism for political/ideological reasons), which is understood as the use of social programs with political-electoral ends. This weakness is closely linked to a limited social participation in the financing of the state health system and a lack of opportunities oriented towards promoting a greater social participation in program design and strategic decision-making. 
Table 2: Strengths on Health Financing

\begin{tabular}{|c|c|c|c|}
\hline \multirow{2}{*}{ Strengths } & \multicolumn{3}{|c|}{ States } \\
\hline & Colima & BC Sur & Jalisco \\
\hline $\begin{array}{c}\text { Negotiation with federal } \\
\text { sources }\end{array}$ & ++ & + & ++ \\
\hline $\begin{array}{c}\text { Negotiation with state } \\
\text { sources }\end{array}$ & ++ & - & +++ \\
\hline $\begin{array}{l}\text { Diversification of } \\
\text { financing sources }\end{array}$ & ++ & + & +++ \\
\hline $\begin{array}{l}\text { Municipalization of } \\
\text { health services }\end{array}$ & - & - & ++ \\
\hline $\begin{array}{c}\text { Consolidated } \\
\text { decentralization }\end{array}$ & + & + & ++ \\
\hline $\begin{array}{l}\text { Combination of } \\
\text { financing funds }\end{array}$ & + & + & ++ \\
\hline $\begin{array}{c}\text { Favorable opinion on } \\
\text { pre-payment }\end{array}$ & ++ & + & ++ \\
\hline $\begin{array}{l}\text { Growth based on goals of } \\
\text { strategic programs }\end{array}$ & + & - & ++ \\
\hline $\begin{array}{l}\text { Implantation of new } \\
\text { financing sources and } \\
\text { schemes }\end{array}$ & ++ & + & +++ \\
\hline Autonomy in spending & ++ & ++ & ++ \\
\hline $\begin{array}{l}\text { Optimization in } \\
\text { expenditures }\end{array}$ & + & + & ++ \\
\hline $\begin{array}{c}\text { Community negotiation } \\
\text { of resources }\end{array}$ & + & + & ++ \\
\hline $\begin{array}{l}\text { Local capacity for } \\
\text { negotiation/fundraising }\end{array}$ & + & & ++ \\
\hline $\begin{array}{l}\text { Resource allocation as a } \\
\text { function of needs }\end{array}$ & + & + & ++ \\
\hline $\begin{array}{c}\text { Perception that financing } \\
\text { has broadened service } \\
\text { production }\end{array}$ & + & + & ++ \\
\hline $\begin{array}{c}\text { Favorable opinions on } \\
\text { recovery fees }\end{array}$ & ++ & ++ & +++ \\
\hline
\end{tabular}

High $=+++$ Medium $=++$ Low $=+$ Nil $=$

These weaknesses were also found, though to a lesser degree, in the analysis of the region C. Federal centralism is the most explicit weakness seen in the analysis of region B.

This situation explains a limited local capacity, in legal frameworks as well as in their ability to move towards a reform of the state health system. Lacks of mechanisms to produce resources and monitor them, as well as the lack of intergovernmental coordination are the weaknesses with greatest specific weight in the study of health system governance for this state. In region A, the political-electoral corporatism, traffic of influences and the problems with efficiency in the production of health services are the weaknesses with greatest specific weight in the analysis of this state (see Table 3).

\section{Results on health financing}

Regarding with trends in expenditures and changes in the composition of health expenditures for the insured population, in region B we observe a growing tendency with a considerable decrease in 1995, but a rapid recovery beginning in 1996; by 2002, there was a considerable increase in health expenditure. We also see that the contributions of the federal level to health expenditures, for the 1990-2002 period, in the states of region B, showed irregular trends. During the first part of the period (1990-1995), we observe decreasing trends which, beginning in 1996, tend to recover in constant pesos as well as in dollars.

The results of trends in health expenditures and changes in expenditure structure, by type of contribution in the states of region A, were similar to those for region $\mathrm{B}$. Trends in health expenditures for the uninsured population are regular, increasing and constant, with no significant fall during any year of the period. The contribution of the federal level to health financing in this state is relatively high and shows irregular trends. Actually, while at the beginning of the period the federal contribution was $94.7 \%$ of total health expenditures, by 1994 the level of participation went down to $87.9 \%$, and went up again at the end of the period; in 2002 this same contribution represented $94.7 \%$ of total health expenditures.

The analyzed financing information of the interviews, suggests that the greatest strengths were associated with a capacity for negotiation, as well as greater opportunities for financing source diversification, and a greater flexibility in regulation frameworks for resource allocation/reallocation.

Strengths in matters of financing have a greater weight when they refer to negotiation, from federal 
Table 3 - Weaknesses on Health Financing

\begin{tabular}{|c|c|c|c|}
\hline \multirow{2}{*}{ Weaknesses } & \multicolumn{3}{|c|}{ States } \\
\cline { 2 - 4 } & Colima & BC Sur & Jalisco \\
\hline $\begin{array}{c}\text { Dependence on } \\
\text { federal level }\end{array}$ & ++ & +++ & ++ \\
\hline $\begin{array}{c}\text { State administrative } \\
\text { recentralization }\end{array}$ & ++ & + & ++ \\
\hline $\begin{array}{c}\text { Limited negotiation } \\
\text { for financial } \\
\text { resources }\end{array}$ & ++ & ++ & + \\
\hline $\begin{array}{c}\text { Lack of knowledge } \\
\text { on financing sources } \\
\text { and funds }\end{array}$ & ++ & ++ & + \\
\hline $\begin{array}{c}\text { Lack of strategic } \\
\text { vision on new federal } \\
\text { sources and schemes }\end{array}$ & + & ++ & + \\
\hline $\begin{array}{c}\text { Uncertain destination } \\
\text { of recovery fees in } \\
\text { view of SPS }\end{array}$ & ++ & ++ & + \\
\hline $\begin{array}{c}\text { An accounting } \\
\text { on recovery fees } \\
\text { follow-up of funds } \\
\text { more difficult }\end{array}$ & ++ \\
\hline $\begin{array}{c}\text { Financial difficulties } \\
\text { due to federal } \\
\text { delegation of } \\
\text { responsitributions }\end{array}$ & ++ & + \\
\hline $\begin{array}{c}\text { Normative rigidity } \\
\text { that limits financial }\end{array}$ & ++ & + \\
\hline
\end{tabular}

High $=+++$ Medium $=++$ Low $=+$ Nil $=$

as well as state sources, as well as the presence of reform strategies linked to the Social Protection System for Health. This activity is represented by new financing and resource allocation schemes, as a function of health needs. The states of region $\mathrm{C}$ show the greatest consistencies which confirm it to be a state with the highest strengths in terms of financing, while region B is the one with the lowest level of strengthening in this area. Some strengths are directly linked to governmental capacities to develop processes with greater autonomy to determine the destination of funds, strengthen negotiations to optimize expenditures, and have a more efficient resource allocation. As an example of this, Jalisco reported a more direct growth in the health system, based on goals of strategic programs and processes with greater autonomy, as well as optimization of expenditures (see Table 4).

Financing weaknesses in state health systems show a lack of negotiating capacity associated with certain dependence on funds contributed by the federal level, particularly in the states of region A and B. This perception is reinforced by a decentralization that is not well consolidated and with limitations of state contributions that are reduced to the financing of the health system. The prevailing level of federal dependence is considered to be the characteristic with greatest weight. For the studies carried out in the states of region A and B, this weakness is added to the characteristic of not having knowledge of fundraising and financing funds, of the uncertain destination of recovery fees as a consequence of the introduction of the Popular Health Insurance; as well as the persistence of accounting systems that make it more difficult to keep track of resources and to have accountability. Other weaknesses reported in region $\mathrm{A}$ and $\mathrm{C}$ refer to the lack of mechanisms to ensure the efficiency of resource allocation from the state sphere to the health system, having as a consequence the activation of administrative recentralization within these states (see Table 5).

\section{Results on equity in health}

The analysis of the information on state systems, for selected states, shows the implementation of plans and programs that are focused on reducing the gap of inequity in sanitary systems as strength in matters of equity. The Popular Health Insurance (PHI) is the one with greatest weight to be catalogued as strength. The results of the analysis also reveal that strengths in matters of equity refer to the establishment of mechanisms for the allocation of resources for the operation and growth of the state health system, as well as the capacity to operate new reform strategies. The immediate consequence of this is an improvement in access to health services demanded by the population. In the particular case of region B, the overall characteristics in matters of equity do not have enough 
Table 4 - Strengths on Equity

\begin{tabular}{|c|c|c|c|}
\hline \multirow{2}{*}{ Strengths } & \multicolumn{3}{|c|}{ States } \\
\hline & Colima & BC Sur & Jalisco \\
\hline $\begin{array}{c}\text { Existence of equity } \\
\text { indicators }\end{array}$ & - & + & ++ \\
\hline $\begin{array}{l}\text { Establishment of } \\
\text { strategies to achieve } \\
\text { optimization of } \\
\text { resources }\end{array}$ & + & + & ++ \\
\hline $\begin{array}{l}\text { Technical criteria in } \\
\text { resource allocation } \\
\text { oriented towards } \\
\text { satisfaction of health } \\
\text { needs }\end{array}$ & + & + & ++ \\
\hline $\begin{array}{c}\text { Resource allocation } \\
\text { for the operation and } \\
\text { growth of the state } \\
\text { health system }\end{array}$ & ++ & - & ++ \\
\hline $\begin{array}{l}\text { Improvement in } \\
\text { opportunities for } \\
\text { healthcare }\end{array}$ & + & + & ++ \\
\hline $\begin{array}{l}\text { Improvement in access } \\
\text { to health services }\end{array}$ & ++ & ++ & ++ \\
\hline $\begin{array}{l}\text { Implementation of } \\
\text { plans and programs } \\
\text { for greater equity (SPS) }\end{array}$ & +++ & ++ & +++ \\
\hline $\begin{array}{c}\text { Capacity to operate } \\
\text { the SPS }\end{array}$ & ++ & + & +++ \\
\hline $\begin{array}{l}\text { Implementation of } \\
\text { plans and programs } \\
\text { to improve financing } \\
\text { (SPS) }\end{array}$ & ++ & ++ & +++ \\
\hline $\begin{array}{l}\text { Existence of programs } \\
\text { for health coverage } \\
\text { and access for } \\
\text { vulnerable populations } \\
\text { (SPS) }\end{array}$ & +++ & + & ++ \\
\hline $\begin{array}{c}\text { Favorable community } \\
\text { impact of health } \\
\text { services }\end{array}$ & ++ & ++ & ++ \\
\hline $\begin{array}{c}\text { Support for the } \\
\text { municipalization of } \\
\text { health services }\end{array}$ & - & - & ++ \\
\hline
\end{tabular}

High $=+++$ Medium $=++$ Low $=+\mathrm{Nil}=$

strengths to consolidate its actions towards a successful health reform (see Table 6).

The greatest weaknesses in matters of equity refer to the allocation of resources to cover local health needs (operational weaknesses - specifi-
Table 5 - Weaknesses in Equity.

\begin{tabular}{|c|c|c|c|}
\hline \multirow{2}{*}{ Weaknesses } & \multicolumn{3}{|c|}{ States } \\
\hline & Colima & BC Sur & Jalisco \\
\hline $\begin{array}{l}\text { Limited management } \\
\text { of equity as financial } \\
\text { allocation criterion }\end{array}$ & ++ & +++ & + \\
\hline $\begin{array}{l}\text { Limitations in state } \\
\text { administration of } \\
\text { resources }\end{array}$ & ++ & ++ & + \\
\hline $\begin{array}{l}\text { Limited management of } \\
\text { formulas for allocation } \\
\text { and use of resources }\end{array}$ & ++ & +++ & + \\
\hline $\begin{array}{c}\text { Out of phase with new } \\
\text { healthcare schemes }\end{array}$ & - & + & - \\
\hline $\begin{array}{c}\text { Lack of capacity to } \\
\text { operate the SPS }\end{array}$ & + & ++ & + \\
\hline $\begin{array}{c}\text { Dependence on citizen } \\
\text { contributions }\end{array}$ & ++ & ++ & ++ \\
\hline $\begin{array}{l}\text { Dependence on } \\
\text { governmental } \\
\text { contributions }\end{array}$ & ++ & +++ & + \\
\hline $\begin{array}{c}\text { References on out-of- } \\
\text { pocket user expenditures }\end{array}$ & ++ & ++ & +++ \\
\hline $\begin{array}{l}\text { Orientation of resources } \\
\text { to cover operative needs } \\
\text { (salary payments) }\end{array}$ & +++ & +++ & ++ \\
\hline $\begin{array}{l}\text { Traditional financing } \\
\text { sources are affected }\end{array}$ & ++ & ++ & ++ \\
\hline $\begin{array}{c}\text { Operative personnel } \\
\text { rejects the SPS }\end{array}$ & + & + & + \\
\hline $\begin{array}{l}\text { Operative expenditures } \\
\text { that may be a financial } \\
\text { burden to the system }\end{array}$ & ++ & ++ & + \\
\hline $\begin{array}{c}\text { Population without access } \\
\text { to programs through pre- } \\
\text { payment }\end{array}$ & + & ++ & + \\
\hline
\end{tabular}

High $=+++$ Medium $=++$ Low $=+$ Nil $=$

cally the payment of salaries to health professionals and those in related areas, and the dependence on resources coming from users' pockets). Also, limitations are reported to be derived from the lack of financial resources to satisfy local health needs of the population. Information about the technical criteria usefulness showed that there is limited handling of equity as a criterion for financial allocation and of formulas oriented towards the allocation and exercise of economic resources; to this we may add the lack of knowledge and application of formulas for resource al- 
location, especially in the region B. The need was established to strengthen state administration of financial resources for health and the perception

Table 6 - Strengths on Governance.

\begin{tabular}{|c|c|c|c|}
\hline \multirow{2}{*}{ Strengths } & \multicolumn{3}{|c|}{ States } \\
\hline & Colima & BC Sur & Jalisco \\
\hline $\begin{array}{l}\text { Identification of legal and } \\
\text { normative frameworks }\end{array}$ & ++ & ++ & +++ \\
\hline $\begin{array}{l}\text { Creation of mechanisms to } \\
\text { improve financing }\end{array}$ & ++ & + & ++ \\
\hline $\begin{array}{c}\text { Mechanisms to monitor the } \\
\text { use of resources }\end{array}$ & + & + & ++ \\
\hline $\begin{array}{c}\text { Margin for local decision- } \\
\text { making }\end{array}$ & ++ & ++ & +++ \\
\hline $\begin{array}{c}\text { Capacity to operate the } \\
\text { health system }\end{array}$ & ++ & + & ++ \\
\hline $\begin{array}{l}\text { Orientation towards } \\
\text { accountability }\end{array}$ & ++ & ++ & +++ \\
\hline $\begin{array}{l}\text { Initiatives to promote } \\
\text { greater participation }\end{array}$ & ++ & + & ++ \\
\hline $\begin{array}{l}\text { Coordination between } \\
\text { government levels }\end{array}$ & ++ & + & +++ \\
\hline $\begin{array}{l}\text { Increased negotiation for } \\
\text { financial resources }\end{array}$ & ++ & + & +++ \\
\hline $\begin{array}{l}\text { Social participation in } \\
\text { fundraising }\end{array}$ & ++ & + & ++ \\
\hline User empowerment & + & + & + \\
\hline $\begin{array}{c}\text { Participation in program } \\
\text { design and in decision- } \\
\text { making }\end{array}$ & - & - & + \\
\hline $\begin{array}{l}\text { Critical vision of political } \\
\text { clientelism with programs } \\
\text { and public resources }\end{array}$ & - & + & + \\
\hline $\begin{array}{c}\text { Community initiatives to } \\
\text { improve well-being }\end{array}$ & + & + & + \\
\hline $\begin{array}{l}\text { Spaces for community } \\
\text { participation (linked to } \\
\text { governmental programs) }\end{array}$ & ++ & + & + \\
\hline $\begin{array}{c}\text { The population sees itself } \\
\text { as being better informed in } \\
\text { health matters }\end{array}$ & + & - & + \\
\hline $\begin{array}{l}\text { Support for community work } \\
\text { to improve health units }\end{array}$ & ++ & + & + \\
\hline $\begin{array}{c}\text { Community involvement in } \\
\text { decision-making }\end{array}$ & - & - & + \\
\hline $\begin{array}{l}\text { Mediation mechanisms to } \\
\text { support vulnerable groups }\end{array}$ & ++ & + & ++ \\
\hline
\end{tabular}

High $=+++$ Medium $=++$ Low $=+$ Nil $=$ of operative personnel who reject or resist the PHI, since they do not know the scope of the program (see Table 7).

For the analysis of indicators for equity in health and trends in resource allocation, we did a comparative analysis between all states. With respect to public expenditures in health as a percentage of the GDP, all states included in the first and second phase of the investigation had public expenditures above the national mean. These are

\section{Table 7 - Weaknesses on Governance}

\begin{tabular}{|c|c|c|c|}
\hline \multirow{2}{*}{ Weaknesses } & \multicolumn{3}{|c|}{ Region } \\
\hline & A & B & C \\
\hline $\begin{array}{l}\text { Limited knowledge of legal } \\
\text { framework and its scopes }\end{array}$ & + & ++ & + \\
\hline $\begin{array}{l}\text { Rigidity of normative } \\
\text { framework }\end{array}$ & + & + & - \\
\hline Limited scopes of the reform & & + & - \\
\hline Federal centralism & + & ++ & + \\
\hline Limited local capacity & - & ++ & - \\
\hline $\begin{array}{l}\text { Efficiency problems in } \\
\text { the production of health } \\
\text { services }\end{array}$ & ++ & ++ & + \\
\hline $\begin{array}{l}\text { Lack of mechanisms to } \\
\text { monitor the use of resources }\end{array}$ & ++ & ++ & + \\
\hline $\begin{array}{c}\text { Lack of intersectorial } \\
\text { coordination }\end{array}$ & + & ++ & + \\
\hline $\begin{array}{c}\text { Cronyism/influence } \\
\text { peddling }\end{array}$ & ++ & ++ & + \\
\hline Political electoral clientelism & ++ & + & + \\
\hline $\begin{array}{l}\text { Social participation in } \\
\text { official programs (Health } \\
\text { Committees) }\end{array}$ & + & + & + \\
\hline Deficient planning & + & + & - \\
\hline $\begin{array}{l}\text { Lack of mechanisms for } \\
\text { increased negotiations of } \\
\text { financial resources }\end{array}$ & + & + & - \\
\hline $\begin{array}{l}\text { Limited social participation } \\
\text { in financing }\end{array}$ & + & ++ & + \\
\hline $\begin{array}{l}\text { Lack of opportunities } \\
\text { for social participation } \\
\text { in program design and } \\
\text { decision-making }\end{array}$ & ++ & ++ & + \\
\hline
\end{tabular}

High $=+++$ Medium $=++$ Low $=+$ Nil $=$ 
the northern states of the country, which allocate less public funds to health, as a proportion of the GDP (see graph 1).

For indicators of per capita public expenditures in health, in most of the states, with the exception of Baja California Sur and Colima, the per capita expenditures assigned to the insured population are greater than those assigned to the insured population. With respect to the per capita expenditures for the uninsured population, we must point out that in the states of Hidalgo and Oaxaca, these are below the national mean, particularly in the case of Oaxaca (see graph 2).

Regarding catastrophic health expenditures, at a national level, and differentiating by type of population, the trends with greatest expenditures are in the uninsured population. The other interesting point is that, contrary to what we would expect, it is the population of the quintile with lowest family income that has the greatest

\section{Graph I: Proportion of Health Public Expenditure in relation to GNP}

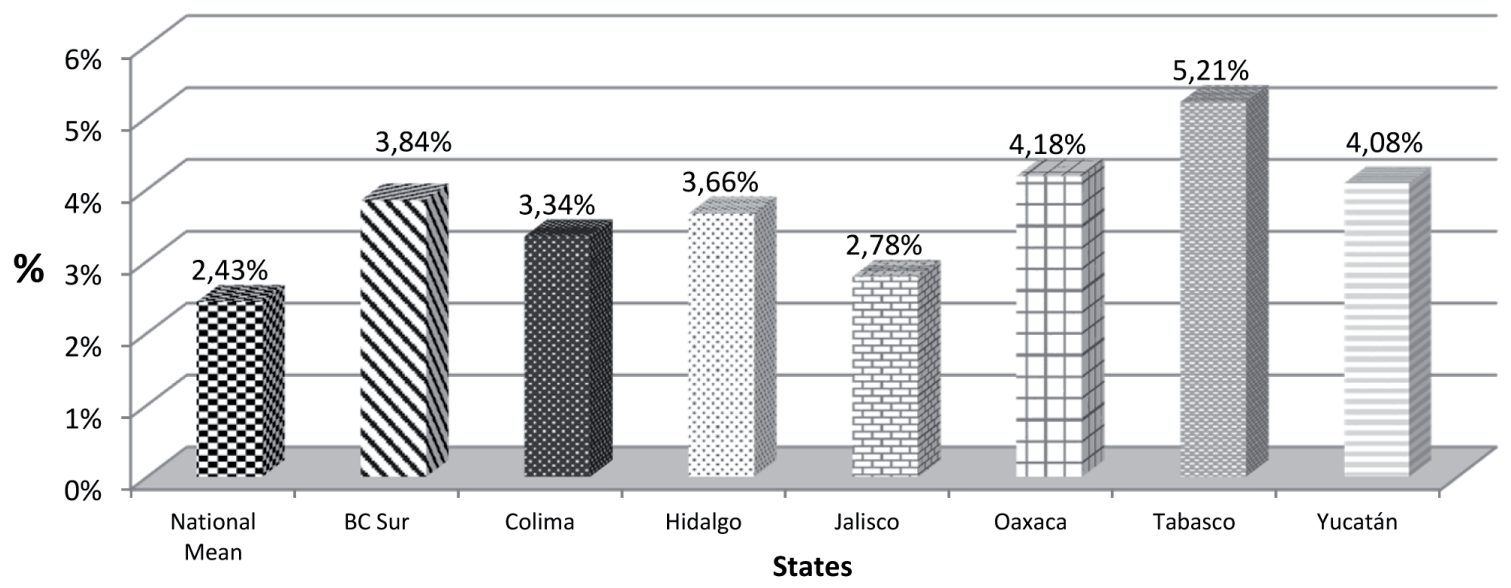

Sources: Secretaria de Salud. Informes Anuales del gasto ejercido. Presupuestos ejercidos por Programas, capitulo e institución. Anuarios y estadísticos de la SSA a nivel Estatal y Municipal, 1999-2010. Proyecto Financiamiento, Equidad, Gobernanza y Descentralización INSP 1999-2010, Arredondo A. y Cols, 20II.

\section{Graph 2: Per Capita Health Public Expenditure for non-Insured Population}

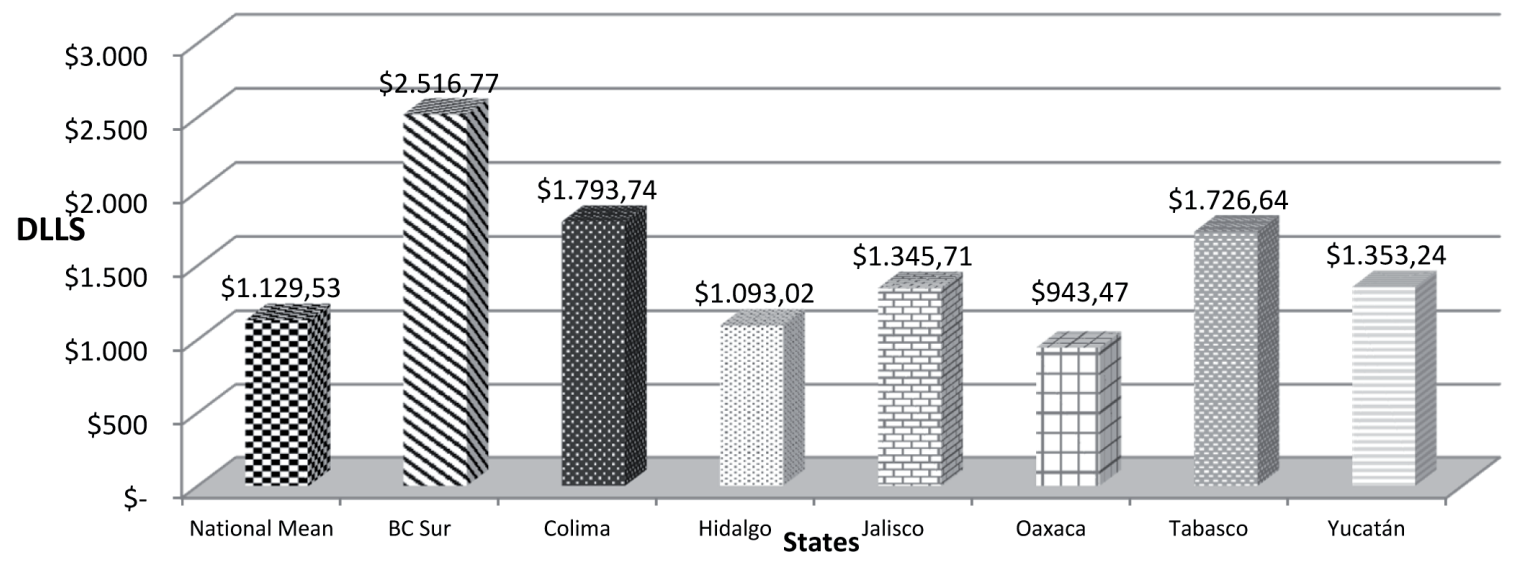

Sources: Secretaria de Salud. Informes Anuales del gasto ejercido. Presupuestos ejercidos por Programas, capitulo e institución. Anuarios y estadísticos de la SSA a nivel Estatal y Municipal, 1999-2010. Proyecto Financiamiento, Equidad, Gobernanza y Descentralización INSP 1999-2010, Arredondo A. y Cols, 20II. 
expenditures in catastrophic health. On trends of catastrophic expenditures in the uninsured population by studied state, Oaxaca had the highest expenditures, while Colima had the lowest (see graph 3).

With respect to the results of the inequity index in resource allocation by state, the states with the highest inequity index were Oaxaca and Hidalgo, followed in decreasing order by Colima, Tabasco, Southern Baja California Sur and Jalisco (see graph 4). The health inequity index refers to inequities in terms of resources allocated based on health needs in each state that is studied. This index is made up of 11 indicators showing expense based on health care program or service type at the level of each state.

\section{Discussion and conclusions}

Integrating the different levels of effects, we highlight the main conclusions on the positive impacts

\section{Graph 3: Catastrophic Expenditure in Health by State}

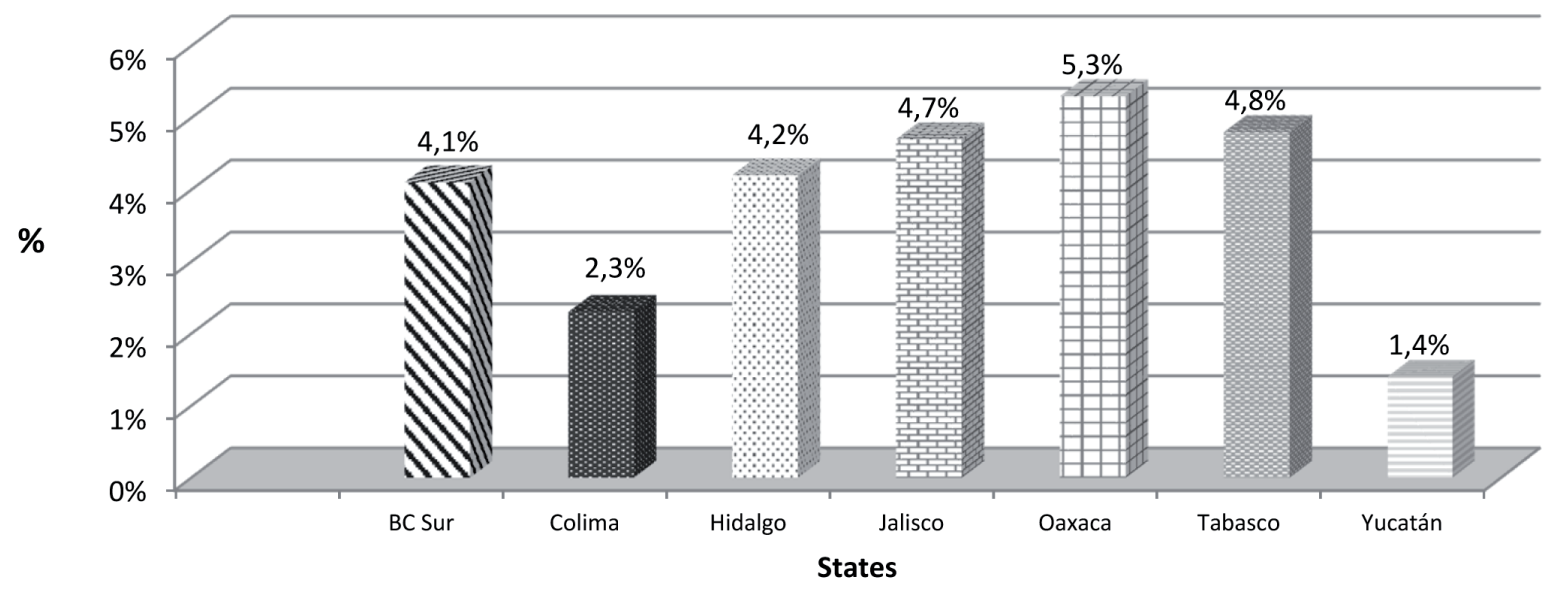

Sources: Secretaria de Salud. Informes Anuales del gasto ejercido. Presupuestos ejercidos por Programas, capitulo e institución. Anuarios y estadísticos de la SSA a nivel Estatal y Municipal, 1999-2010. Proyecto Financiamiento, Equidad, Gobernanza y Descentralización INSP 1999-2010, Arredondo A. y Cols, 20II.

\section{Graphic 4: Health Inequity Index in States under study}

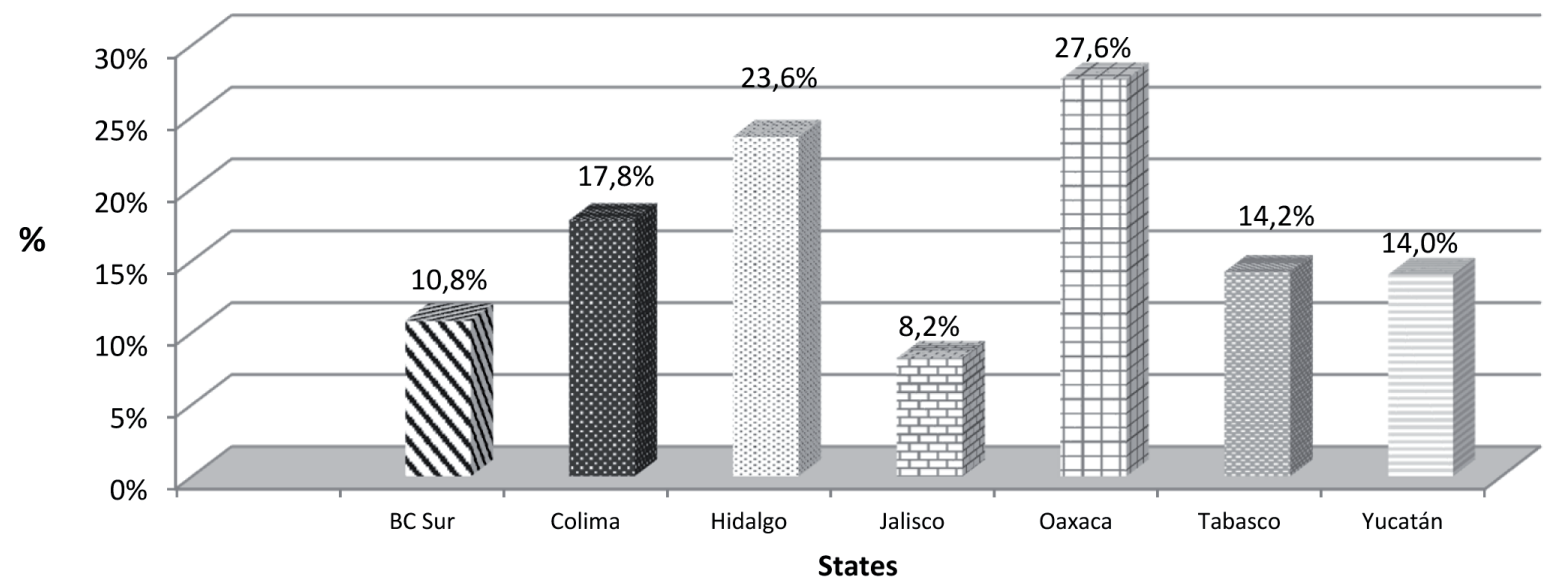

Sources: Secretaria de Salud. Informes Anuales del gasto ejercido. Presupuestos ejercidos por Programas, capitulo e institución. Anuarios y estadísticos de la SSA a nivel Estatal y Municipal, 1999-2010. Proyecto Financiamiento, Equidad, Gobernanza y Descentralización INSP 1999-2010, Arredondo A. y Cols, 20II. 
(strengths) and negative impacts (weaknesses) for the advance of health reforms. Special emphasis is placed on the analysis of lessons learned in Mexico and the usefulness of the main strengths and weaknesses as relevant suggestions or recommendations for other Latin American countries which are designing, implementing and evaluating reform strategies in order to achieve equity in resource allocation, good levels of governance and greater financial protection in health.

\section{Main Lessons on Strengths}

- Decentralization as a strategy in force for health reform has generated considerable gains in terms of indexes of financial co-responsibility and co-responsibility in health production and participation.

- After decentralization, considerable increases have been reported in health financing money and increasingly effective mechanisms for the coordination of government levels in health in most of the study states; these changes have coincided with positive gains in some social indicators, particularly improvement in child mortality rates, maternal mortality and morbidity due to chronic and infectious diseases.

- In matters of equity, there is a new formula for resource allocation and the states have played a leading role in its revision, adjustments and application, to make the resources assigned by the federal level more adequate, as well as the reallocation of resources based on the healthcare model adopted by each state as a function of its needs.

- The implementation of priority health programs directed at the most vulnerable groups has contributed greatly in guaranteeing greater financial protection, more access and greater coverage for marginalized families. The financial protection health strategy has prevented catastrophic health expenditures in some states and, as a result, the further impoverishment of the most vulnerable families.

- There is evidence of improvement in health system performance indicators which coincide with the implementation of the described changes.

- The Popular Health Insurance (PHI) is a financing strategy with an equity principle, wherein financing follows the user if he/she moves from one state to another. This is particularly relevant in a country where the internal migration of the population not belonging to the formal economy is so high.

- Different actors in the health system have taken on a more active role in health-related decisionmaking. Among these actors, the users of services granted by some priority health programs stand out, as well as NGO leaders and leaders of health commissions in the states' legislative bodies.

\section{Main Lessons on Weaknesses}

- From the time decentralization began as a reform strategy, it has been very difficult to create more or less homogenous effectiveness in all states when implementing health reforms and programs directed at vulnerable groups.

- There is confusion among the different levels of government when implementing changes in financing and health service production. The municipal level claims that the state level is the one now centralizing power.

- Accountability at the federal level is limited to providing information about the fulfillment of goals in all substantial programs and supporting them, without relating to a measurable denominator that would allow for effective accountability. In the states and municipalities, a system for accountability and transparency in resource allocation is still absent.

- Priority health programs directed at vulnerable groups operate with centralized management at the federal level, with effects that are contrary to the gains that had been generated by the decentralization of power and with limited effects on mechanisms to coordinate these programs and on benefits in epidemiological indicators for health.

- Disagreements between political parties in power in federal and state governments create low levels of governance and difficulty with the effective management of some priority programs.

- In spite of improved financial protection, in some states users with low family income are the ones who have greater catastrophic health expenditures.

- Measures used to improve resource allocation equity for the uninsured population have not been sufficient. There are high indexes of inequity, particularly in the states included in this study that have greater marginalization. 


\section{Lessons and recommendations}

\section{In Matters of Financing}

1. The local levels should have an allocation mechanism that is not only based on historical criteria but which also uses and promotes epidemiological, economic and clinical criteria in all allocation processes, with greater intensity and with different strategies, as well as an efficient use of financial resources.

2. Promote total autonomy at the local level so that, based on an integral plan, it may regulate negotiations for and use of financial resources, independently of the origin of the financing sources.

3. Implement a costs/productivity system at Health Services which will allow them to oppose the integration of historical budgets and normalize their integration into the productivity system. (In parallel, regulate, readdress and update the State Accounts System for Health to give it real usefulness so that it will not only be a tool for electronic updating).

4. Accelerate the process and make the rights and responsibilities of the states more precise when signing agreements in matters of financing changes and in the production of services to the Social Protection System in Health.

5. Periodically revise and evaluate changes in financing with respect to the Agreement for Decentralization in a coordinated manner with the federal and state levels. Take the results to the Technical Council in Health for discussion.

\section{In Matters of Equity}

1. Besides promoting epidemiological, organizational and economic criteria in the allocation of health resources, incorporate new technical criteria in budgetary allocation that considers health needs, economic vulnerability, productivity, complexity of care levels, accessibility and financial capacity of states.

2. Regulate public policy at the state and federal levels for the design and implementation of a formula for an equitable resource allocation, discussed and endorsed by a technical committee with participation, not only of municipal, state and federal government levels, but also with the participation of all possible actors in the health system and society.
3. Ensure congruence in resource allocation between the federation and the states, and between the states and the municipalities, as a function of social marginalization, the users' purchasing power, the epidemiological lag and the installed capacity.

4. Establish mechanisms and strategies that will guarantee accessibility to health services, privileging criteria for social justice and financial protection in health, above all in the states with a greater catastrophic expenditure index and greater inequity indexes.

5. Monitor and evaluate, through a committee that is external to the federal health sector, the Social Protection System in Health, prioritizing the affiliation and strengthening of the supply of services (greater resources and infrastructure) for the vulnerable population.

\section{In Matters of Governance}

1. Progress in the democratization of health. For this it will be necessary to set forth rules, actors, roles and processes with greater clarity, precision and feasibility, which will allow the system to reach improved levels of governance and a greater capacity for management and effectiveness in reform strategies.

2. Promote the legitimization of agreements between health authorities, government, civil society, NGO's, legislative authorities and political parties to conduct reform strategies. Define groups and $\mathrm{ad}$ hoc mechanisms for the monitoring of processes directed at improved governance. These groups must negotiate the implementation of accountability systems.

3. Generate obligatory spaces at federal, state and municipal levels for accountability with accessible information on results of health indicators, as well as the efficient and non-discretional use of resources. In this sense, create groups at the federal, state and municipal levels (with the participation of all actors) for a critical review of results on accountability.

4. Generate, produce and disseminate a bulletin on health governance among all social actors that includes conceptual, methodological, political and empirical aspects of good health governance in the public health system. 
5. Establish required mechanisms that will prevent and sanction discretionality in the use and allocation of resources (human, material and financial) while promoting mechanisms to allow the endorsing citizen to have greater interaction with legislative and health authorities.

\section{References}

ALONSO, J. Gobernanza y politicas públicas. In: . El nuevo estado mexicano. México, DF:

Nueva Imagen: CIESAS, 2012. p. 135-148.

ARREDONDO, A.; OROZCO, E. Governance and equity from health care reform in Mexico. International Journal of Health Planning and Management, Keele, v. 23, n. 1, p. 37-49, 2008

ARREDONDO, A. et al. Estrategias de reforma y protección social en salud en México: segunda parte: efectos en financiamiento y gobernanza. Cuadernos Médico Sociales de Chile, Santiago, v. 5o, n. 3, p. 178-192, 2011.

ARREDONDO, A. et al. Temas selectos en sistemas de salud: costos, financiamiento, equidad y gobernanza: conceptos, tendencias y evidencias. Mérida: Universidad Autónoma de Yucatán, 2009.

BRAVEMAN, P.; GRUSKIN, S. Poverty, equity, human rights and health. Bulletin of the World Health Organization, Geneva, v. 81, n. 7, p. 539-545, 2003.

CASSELS, A. Health sector reform: key issues in less developed countries. Journal of International Development, Oxford, v. 7, n. 3, p. 329-347, 1995.

\section{EOHS - EUROPEAN OBSERVATORY OF HEALTH}

SYSTEMS. Health care systems in transition: organizational structure and management. Copenhagen: WHO, 2010.

EXELLE, B. D.; HERDT, T. D. The fairness concerns in social protection and poverty reduction. Antwerp: University of Antwerp, Institute of Development Policy and Management, 2009. FRANCO, A.; GIL, D.; ÁLVAREZ, C. Tamaño del Estado (gasto público) y salud en el mundo, 1990200o. Gaceta Sanitaria, Barcelona, v. 19, n. 3, p. 186-192, 2005
FRENK J. et al. Demanda y oferta de servicios médicos: obstáculos a la mejoría del sistema de salud en México. México, DF: FUNSALUD, 1994. HORVATH, T. Decentralization: experiments and reforms: local government and public service reform initiative. Washington, DC: Open Society Institute. 2002.

IMSS - INSTITUTO MEXICANO DEL SEGURO SOCIAL. Anuario estadístico de servicios medicos: 1980-2010. México, DF, 2011

MÉXICO. Secretaría de Salud. Consejo Nacional de Vacunación. Programa de Atención a la Salud del Niño: manual de procedimientos técnicos. México, DF, 2009.

MÉXICO. Secretaría de Salud. Anuario estadístico 1993-2010. México, DF: Dirección General de Estadística e Informática: SSA, $2010 a$.

MÉXICO. Reglamento Interno del Consejo Nacional de Protección Social en Salud. Diario Oficial de la Federación, México, DF, 8 jul. 2010b. p. 1-5.

MÉXICO. Comisión Nacional de Protección Social en Salud. Programa Nacional de Salud y Seguro Popular. México, DF: SSA, 2012a.

MÉXICO. Instituto Nacional de Estadística, Geografía e Informática. Anuarios estadísticos por estado: Oaxaca, Colima, Hidalgo, Tabasco, Baja California Sur y Jalisco: 1990-2010. México, DF, $2012 \mathrm{~b}$.

MÉXICO. Secretaría de Salud. Compendio histórico: estadísticas vitales 1893-2011 EUM. México, DF: Dirección General de Estadística, Informática y Evaluación, 2012c.

MÉXICO. Instituto Nacional de Salud Pública. Encuesta Nacional de Nutrición 2012: niños menores de cinco años. Cuernavaca, 2013a.

MÉXICO. Poder Ejecutivo Federal. Secretaría de Salud. Programa de Reforma del Sector Salud 2006-2012 e 2012-2018. México, DF, 2013b.

MOSER, K. A.; LEON, D. A.; GWATKIN, D. R. How does progress towards the child mortality millennium development goal affect inequalities between the poorest and least poor?: analysis of demographic and health survey data. British 
Medical Journal, London, v. 331, p. 1180-1182, Nov. 2005 .

OCDE - ORGANIZACIÓN PARA LA COOPERACIÓN Y EL DESARROLLO ECONÓMICOS. Estudios de la OCDE sobre los sistemas de salud: México. México, DF, 2011.

RANSON, K. Reduction of catastrophic health care expenditures by a community-based health insurance scheme in Gujarat, India: current experiences and challenges. Bulletin of the World Health Organization, Geneva, v. 80, n.8, p. 613-621, 2004 .

WHO EQUITY TEAM. Priorities for research to take forward the health equity policy agenda, Bulletin of the World Health Organization, Geneva, v. 83, n. 12, p. 948-953, 2005 .

\section{Authors' Contribution}

Arredondo coordinated, guided, systemized and conducted the theoretical development. Orozco and Aviles conducted the field work research and tabulated and systemized the data.

Received: $29 / 11 / 2013$

Resubmitted: 15/04/2014

Approved: 16/05/2015 